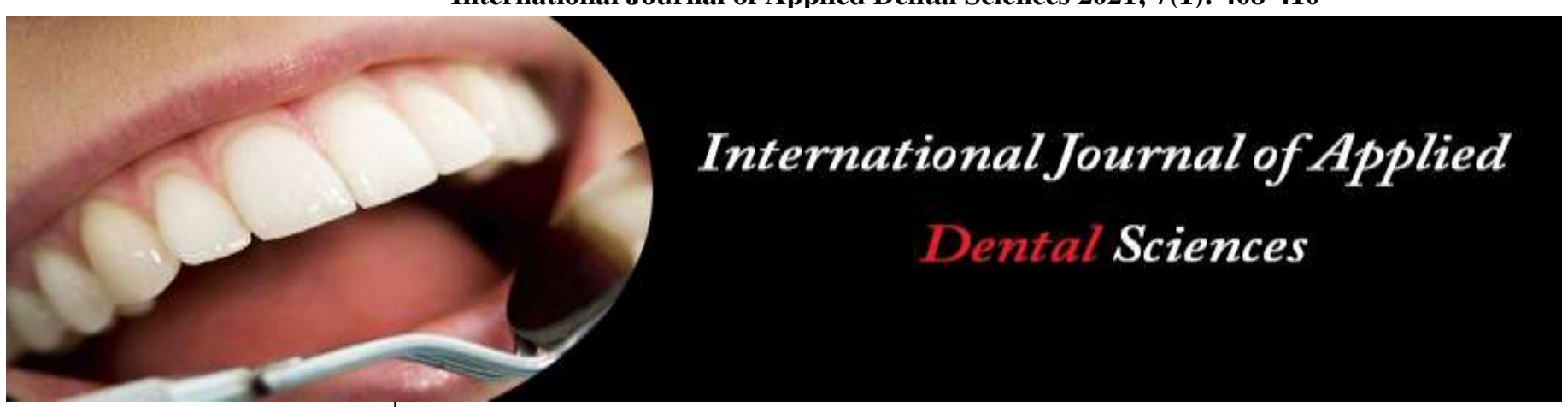

ISSN Print: 2394-7489

ISSN Online: 2394-7497

IJADS 2021; 7(1): 408-410

(C) 2021 IJADS

www.oraljournal.com

Received: 22-12-2020

Accepted: 10-01-2021

\section{Dr. M Das}

a) Ph.D. Scholar,

Department of Oral and Dental

Sciences, JIS University,

Kolkata, West Bengal, India

b) Assistant Professor,

Department of Pedodontics and

Preventive Dentistry, Dr. R

Ahmed Dental College and

Hospital, Kolkata, West Bengal,

India

\section{Dr. AN Chatterjee}

$3^{\text {rd }}$ Year PGT, Department of

Pedodontics and Preventive

Dentistry, Dr. R Ahmed Dental College and Hospital, Kolkata,

West Bengal, India
Corresponding Author: Dr. M Das

a) Ph.D. Scholar,

Department of Oral and Dental

Sciences, JIS University,

Kolkata, West Bengal, India

b) Assistant Professor,

Department of Pedodontics and

Preventive Dentistry, Dr. R

Ahmed Dental College and

Hospital, Kolkata, West Bengal,

India

\section{Management of furcal involvement with Portland cement: A new approach to save a hopeless tooth}

\author{
Dr. M Das and Dr. AN Chatterjee
}

DOI: https://doi.org/10.22271/oral.2021.v7.i1f.1161

\section{Abstract}

Be it a root canal perforation or a furcal involvement, MTA has proven itself to be the material of choice for repair of the same. But it may not be the easiest available material for treatment every time. In this era of conservative treatment that too in a minimally invasive manner extraction of tooth due to nonavailability of material is not acceptable. There are a huge list of materials available which has been a full-proof material for the furcation repair. But Portland cement is one such material which is easily available and can be treated to make it usable in the oral cavity.

This paper aims to present a case where chronic pulpal inflammation had led to furcal involvement of the lower first molar tooth which has been treated with Portland cement.

Keywords: First molar, furcation repair, Portland cement

\section{Introduction}

Conservative treatment modalities of multi-rooted teeth often presents with various procedural complications such as perforations which may be either iatrogenic or due to chronic pathological process itself ${ }^{[1,2,3]}$. The treatment planning of furcation involvement is always a dilemma for the dentist to take a decision whether it would be better with endodontic preservation or extraction. Furcal involvement may occur during preparation of access cavities, post space preparation or as a result of extension of internal resorption into the periradicular space ${ }^{[4]}$. It leads to loss of integrity of the root structure and causes damage to the periodontal tissues. The prognosis of cases depends on the proper sealing of the tooth at the perforation site and the use of suitable material that reduces the inflammation of the periodontal tissues ${ }^{[5]}$.

The Ideal requirements of materials for perforation repair include- 1) It should provide adequate seal, 2) It should be biocompatible, 3) It should have ability to induce osteogenesis and cemento-genesis, 4) It should be bacteriostatic, and radiopaque 5) It should be relatively inexpensive, 6) It should be non-toxic, non-cariogenic and easy to place and 7) It should also be beneficial to use a resorbable matrix in which a sealing material can be condensed ${ }^{[6]}$. Surprisingly, no material offers all of these properties. In search for the ideal material, numerous sealing materials and techniques have been tested over the years with varying success. The various materials that have been used for the perforation repair include glass ionomer cement (GIC), composite, dentinchips, decalcified freeze dried bone, calcium phosphate cement, tri-calciumphosphate cement, hydroxy-apatite crystals, mineral trioxide aggregate (MTA), bio-dentine, bio-aggregate, Portland cement and others.

The advent of MTA has changed this scenario because of its favorable chemical and biological properties ${ }^{[7]}$. At present, MTA is the most indicated material for the repair of root canals. The major components of ordinary Portland cement, which are similar to those of MTA, consist of tri-calcium silicate, di-calcium silicate, tri-calciumaluminate, tetra-calcium aluminoferrate, and calcium sulfate dehydrate ${ }^{[8,9]}$. Studies comparing the properties of MTA and Portland cement have reported that their $\mathrm{pH}^{[10,11]}$, antimicrobial activities ${ }^{[12]}$, biocompatibility ${ }^{[13]}$, and low resistance to compression ${ }^{[14]}$ are similar. This article presents a review and case report of perforation repair with Portland cement. 


\section{Case report}

A 10 years old girl child reported to the outpatient department with grossly decayed lower right back tooth. On examination, it was found that 46 was grossly carious. Intra-oral periapical radiograph showed furcation involvement with inter-radicular radiolucency with horizontal inter-alveolar bone loss. Notably, there was no radiolucency present in peiapical region. After thorough evaluation of clinical situation and patient-parent desire, we have planned to take an attempt to restore the mutilated tooth repairing the perforation with
Portland cement followed by endodontic treatment.

In first phase, Portland cement is prepared from crude white cement by disinfecting it in hot air oven. In second phase, after obtaining written parental consent, access cavity of 46 was made with proper isolation. Working length determination and biomechanical preparation done subsequently. Portland cement was mixed with bismuth oxide in 3:1 ratio for radio-opacity and placed on the perforation site blocking the canals withgutta percha points.

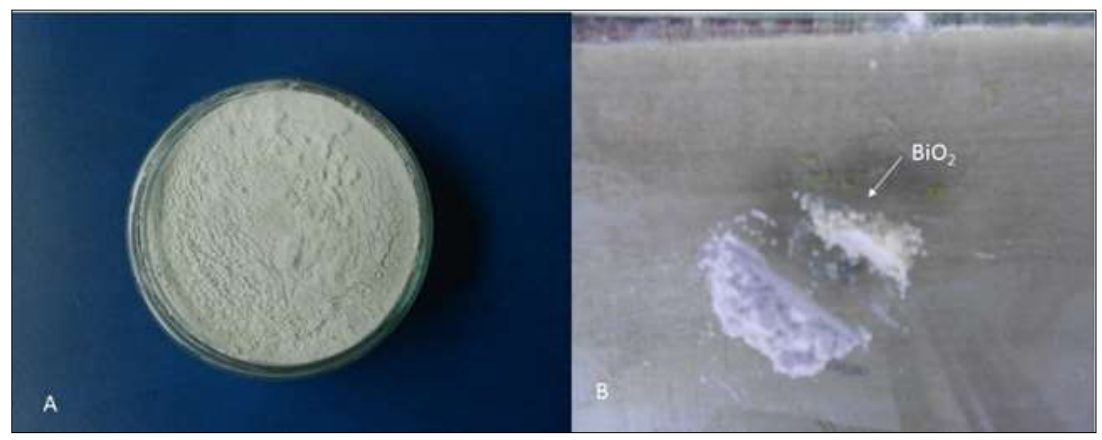

Fig 1: Preparation of Portland cement - (A) Sterilised Portland cement (B) Proportion of Portland cement and bismuth oxide (3:1)

Next, canals are obturated with GP and zinc oxide sealer and access cavity was sealed with type II GIC. On $7^{\text {th }}$ day, patient was clinically asymptomatic. After 21 days, radiographic signs of healing were evident and semi-permanent full coverage restoration was planned as 47 was erupting. In the $4^{\text {th }}$ appointment, crown preparation was done and stainless steel crown was cemented with type I GIC. Post-operative instructions are given and follow up advised for $3^{\text {rd }}$ and $6^{\text {th }}$ month intervals.

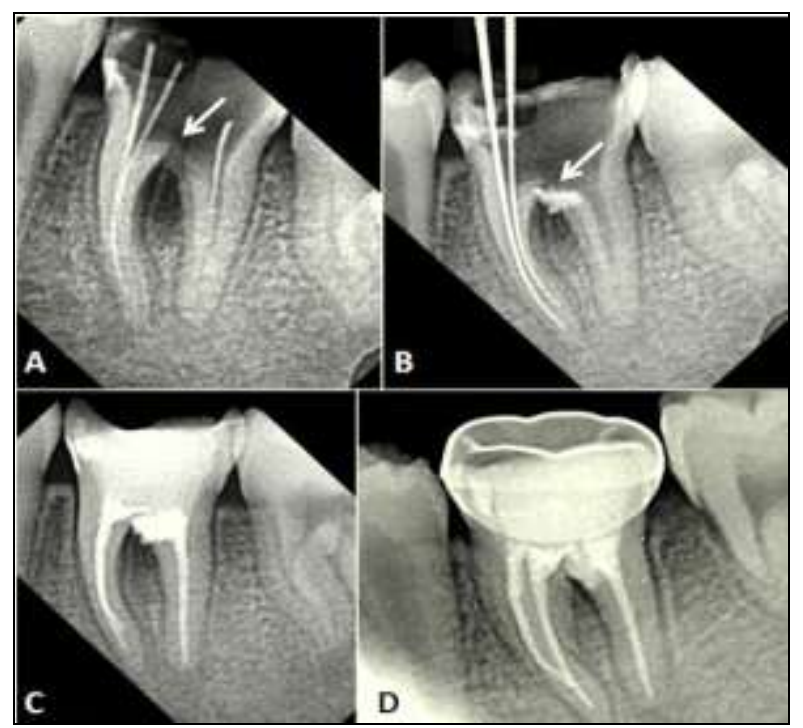

Fig 2: Furcation management with Portland cement (A) Preoperative picture showing furcation involvement with diagnostic guttapercha (B) Furcation management with placement of Portland cement (C) Post-operative radiograph with obturated canals (D)

Radiograph showing $21^{\text {st }}$ day follow-up with semi-permanent restoration (Stainless steel crown)]

\section{Discussion}

For successful furcation repair, three crucial factors can be considered-1. Time elapsed between the occurrence of the defect and repair, 2. The ability of the material to seal the site, 3. Biocompatibility and compressive strength of the material [15-17]. Here, in this case, we have chosen Portland cement instead of MTA based on its physical properties including the sealing ability, cost-effectiveness and availability. Several studies demonstrated effective perforation repair with MTA and Portland cement. In an animal study, Neto JDS et al. ${ }^{[18]}$ conducted furcation repair in premolarsusing MTA and Portland Cement (typeII and typeV) and found that after 120 days the bone formed in the furcation area showed no significant difference for both materials. Tsatsas DV et al. in 2005 conducted an in-vitro study on ninety human molars and used different materials for furcation repair like Mineral Trioxide Aggregate (ProRootM ${ }^{\sim}$ ), Super-EBA, Vitremer, Hemarcol together with Super-EBA, Hemarcol together with Vitremer, Tricalcium phosphate together with AH26, Cavit W and amalgam ${ }^{[19]}$. It was found that MTA alone or vitremer in combination with collagen sponge could effectively seal the area of the furcation. Interestingly, Shahi S et al., 2009 [20] showed better sealing ability of Portland cement compared to MTA.

It has been shown by various authors that MTA is the desired material of choice for any kind of furcation or perforation repair ${ }^{[14]}$. The components of MTA are similar to Portland cement except that of bismuth oxide. Portland cement bears similar biological and chemical properties as MTA; release of calcium ion occurs that leads to carbonate apatite formation which promotes bio-mineralisation. Either MTA or Portland cement, both are hygroscopic material that promotes expansion and seals the defect. During the hydration process, the calcium silicates react to form a calcium hydroxide and hydrous silicate gel with a high alkaline $\mathrm{pH}[21,22]$. Furthermore, Portland cement provides cell adhesion and differentiation stimulating the mineralized tissue formation. The use of Portland cements with additives, which have high resistance to compression, may contribute to the long-term success of the repair of furcation perforations, because this is an area subject to high masticatory loads ${ }^{[23]}$. Considering all the advantages, Portland cement can be a material of choice for furcation repair in recent time.

\section{Conclusion}

Bio-mineralisation and bio-compatibility of Portland cement are almost similar with MTA. Limitations like commercial 
unavailability are a genuine problem but pre-operative preparation of Portland cement from crude material is an easy process that can be done manually. Further studies are required using Portland cement to make it a popular material for perforation repair to substitute MTA in regular clinical practice.

\section{References}

1. LambrianidisTh. Risk management in root canal treatment: perforation. Thessaloniki: University Studio Press 2001, P85-144.

2. Frank RJ. Endodontic mishaps: Their detection, correction and prevention. In: Ingle J, Bakland L eds. Endodontics. Hamilton, London: BC Decker Inc 2002, P769-94.

3. Camargo CH, Fonseca MB, Carvalho AS, Camargo SE, Cardoso FG, Valera MC. Microhardness and sealingability of materials used for root canal perforations, General Dentistry 2012;60:e393-e397.

4. Fuss Z, Trope M. Root perforations: Classifications and treatment choices based on prognostic factors. Endod Dent Traumatol 1996;12:255-264.

5. Bryan EB, Woollard G, Mitchell WC. Nonsurgical repair of furcal perforations: a literature review. Gen Dent 1999;47:274-278.

6. Hartwell GR, England MC. Healing of furcation perforation in primate teeth after repair with decalcified freeze dried bone: a longitudinal study. J Endod 1993;19:357-61.

7. Torabinejad M, Watson TF, Pitt Ford TF. Sealing ability of a mineral trioxide aggregate when used as a root end filling material. J Endod 1993;19(12):591-5.

8. Tolentino E, Lameiras FS, Gomes AM, Silva CAR, Vasconcelos WL. Effects of high temperature on the residual performance of Portland cement concretes. Mat Res 2002;5(3):301-7.

9. Deal BF, Wenckus CS, Johnson BR, Fayad MI. Chemical and physical properties of MTA, Portland cement and a new experimental material, fast-set MTA. J Endod 2002;28(3):252-6.

10. Holland R, de Souza V, Murata SS, Nery MJ, Bernabé PF, OtoboniFilho JA, DezanJúnior E. Healing process of dog dental pulp after pulpotomy and pulp covering with mineral trioxide aggregate or Portland cement. Braz Dent J 2001;12(2):109-13.

11. Abdullah D, Ford TR, Papaioannou S, Nicholson J, McDonald F. An evaluation of accelerated Portland cement as a restorative material. $\mathrm{J}$ Endod 2002;23(19):4001-10.

12. Estrela C, Bammann LL, Estela CR, Silva RS, Pécora JD. Antimicrobial and chemical study of MTA, Portland cement, calcium hydroxide paste, Sealapex and Dycal. Braz Dent J 2000;11(1):3-9.

13. Trindade AC, Oliveira EP, Figueiredo JÁ. Comparative analysis of the tissue response to mineral trioxide aggregate (MTA), Portland cement and Portland cement to radiopaque substance. J Bras Endod 2003;4(15):30914.

14. Húngaro Duarte MA, de Oliveira El Kadre GD, Vivan RR, GuerreiroTanomaru JM, TanomaruFilho M, de Moraes IG. Radiopacity of Portland cement associated with different radiopacifying agents. $\mathrm{J}$ Endod 2009;35(5):737-40.

15. Seltzer S, Sinai I, Augut D. Periodontal effects of root perforations before and during endodontic procedures. $\mathrm{J}$
DentRes 1970;49:332-39.

16. Guttman JL, Damsha TC, Lovdhi PE, Hovland EJ. Problem solving in Endodontics. $3^{\text {rd }} \mathrm{ed}$, Mosby, St. Lous 1997, P19, 41, 73, 96.

17. Balla R, LoMonaco CJ, Skribner J, Lin LM. Histological study of furcation perforations treated with tricalciumphosphate, hydroxylapatite, amalgam and life. J Endod 1991;17:234-38.

18. Neto JDS, Schnaider TB, Gragnani A, Paiva AP, Novo NF, Ferriera LM. Portland cement with additives in the repair of furcation perforations in dogs. Acta Cirúrgica Brasileira 2012;27(11):809.

19. Tsatsas DV, Meliou HA, Kerezoudis NP. Sealing effectiveness of materials used in furcation perforation in vitro. International Dental Journal 2005;55:133-141.

20. Shahi S, Rahimi S, Hasan M, Shiezadeh V, Abdolrahimi M. Sealing ability of mineral trioxide aggregate and Portland cement for furcal perforation repair: A protein leakage study. J Oral Sci 2009;51:601-06.

21. Camilleri J. "Hydration mechanisms of mineral trioxide aggregate," International Endodontic Journal 2007;40(6):462-470.

22. Bogen G, Kuttler S. Mineral trioxide aggregate obturation:a review and case series. Journal of Endodontics 2009;35(6):777-790.

23. Peters CI, Peters OA. Occlusal loading of EBA and MTA root-end fillings in a computer-controlled masticator: A scanning electronmicroscopic study. Int Endod $\mathrm{J}$ 2002;35(1):22-9. 